\title{
Characterization and habitat preferences by white-tailed deer in Mexico
}

\author{
JOAQUIN BELLO, SONIA GALLINA, AND MIGUEL EQUIHUA
}

The authors are a graduate student, Programa de Ecología y Manejo de Recursos Naturales (Ecology and Natural Resource Management Program); Full Researcher, Departamento de Ecología y Comportamiento Animal (Department of Animal Ecology and Behavior); Full Researcher, Departamento de Ecología y Conservación de Ecosistemas Templados (Department of Ecology and Conservation of Temperate Ecosystems); all at the Instituto de Ecología, A.C., km 2.5 Carretera Antigua a Coatepec, \#351, Congregación el Haya, A.P. 63 Xalapa 91070, Veracruz, México.

\section{Abstract}

We analyzed the habitat preferences of white-tailed deer in a 1,000 ha area in an arid region of northeastern Mexico where drinking water is abundant throughout the year (via 33 water troughs). Seven habitat types in the study area were identified and characterized. Within each habitat, feeding, searching, and bedding activities were evaluated during the reproduction, postreproduction and fawning seasons of the annual deer cycle. The Acacia-Celtis habitat provided the greatest amount of hiding and thermal cover and edible food. The Prosopis habitat also provided significant hiding and thermal cover. Hilaria and Opuntia were the most open habitats. Habitat preferences, evaluated by radiotracking 14 deer over a period of 2 years, varied between sexes and years $(P<<0.00001)$, but not among seasons $(P>0.05)$. Male deer preferred open habitats, while females preferred more densely covered ones. Males and females avoided Prosopis during 1996. Both sexes distributed the 3 activities more evenly during 1996 than during 1995 . In 1995 , females preferred Flourensia and Acacia-Celtis habitats for all activities, and during 1996 males preferred Hilaria and Leucophyllum. Between year changes in precipitation could explain the observed variability: during 1995 rainfall was $136 \mathrm{~mm}$, as compared to $276 \mathrm{~mm}$ in 1996. Requirements for cover increased markedly in 1995 due to high predation and extremely dry conditions. Overall, our study shows that under good weather conditions, habitat preferences are best explained by variables associated with food availability, while thermal cover is more important under harsh weather conditions, even when drinking water is abundant.

Key Words: Odocoileus virginianus, Northeastern zone, water sources, radiotelemetry, hiding cover, thermal cover, forage.

White-tailed deer (Odocoileus virginianus) are selective foragers and prefer habitats with plants that meet their nutritional requirements. Additionally, to decrease the risk of predation and dehydration under extreme conditions, deer select habitats based on the degree of cover (Bleich et al. 1997, Bowyer et al. 1998).

This research was funded by the Consejo Nacional de Ciencia y Tecnología (Conacyt), Project No. 225260-5-2480PB. Ducks Unlimited de Mexico A.C. (DUMAC) provided important logistical support. C. Delfín, N.D. López, S. Mandujano and A Pérez-Arteaga assisted with data collection. The authors thank Fernando Cervantes for reviewing the initial version of the manuscript in Spanish; Ingrid Anna Crews Márquez for translating the original version into English, and John Laundré and Robert Manson for reviewing the manuscript in English. We are grateful to Bianca Delfosse for her careful review and editing of the final manuscript.

Manuscript accepted 9 Dec. 00.

\section{Resumen}

Analizamos las preferencias de hábitat del venado cola blanca en un área de 1,000 ha, de la región árida del Noreste de México donde el agua para tomar es abundante todo el año (33 bebederos). Fueron identificados y caracterizados los siete tipos de hábitat de la zona de estudio. Dentro de cada hábitat, las actividades alimentación, búsqueda y descanso, fueron evaluadas durante las 3 épocas del ciclo anual del venado: reproducción, postreproducción y crianza. El hábitat de Acacia-Celtis tuvo los valores más altos de cobertura de protección y térmica, así como de alimento disponible. El hábitat Prosopis tuvo valores altos de cobertura térmica y de protección. Hilaria y Opuntia fueron los hábitats más abiertos. Las preferencias de hábitat, evaluadas mediante radiotelemetría de 14 venados durante un período de 2 años, variaron entre sexos y años $(P \ll 0.00001)$, pero no entre épocas $(P>0.05)$. Los machos prefirieron los hábitats abiertos $y$ las hembras los de cobertura más densa. Machos y hembras no prefirieron la vegetación de Prosopis durante 1996. Ambos sexos distribuyeron de manera más uniforme sus actividades durante 1996 en comparación con 1995. En 1995, las hembras prefirieron para todas sus actividades a los hábitats de Flourensia y AcaciaCeltis, y en 1996 los machos prefirieron a Hilaria y Leucophyllum. Los cambios entre años en la precipitación pueden explicar la variabilidad observada: durante 1995 la precipitación fue de 136 mm, en comparación con los $276 \mathrm{~mm}$ en 1996. Los requerimientos de cobertura se incrementaron en 1995 debido a la alta depredación y las condiciones extremas de sequía. Nuestro estudio demuestra que en condiciones ambientales buenas, las preferencias de hábitat son mejor explicadas por las variables relacionadas con el alimento disponible, mientras que la cobertura térmica aumenta su importancia en condiciones ambientales extremas, a pesar de la alta disponibilidad de agua.

When temperatures are high and water scarce, deer use habitats with high thermal cover, which can minimize water loss (Bowyer et al. 1998). However, Boroski and Mossman (1996) mentioned that when water distribution is adequate, the distribution of deer is probably determined by other factors in their environment. The importance of water sources for deer in arid environments (Davis 1990) and the close association between vegetation cover and the presence of water under dry conditions, make it difficult to detect other factors that may affect habitat preference by deer. Studies conducted where water availability is high and constant may further our understanding of other factors important in habitat selection by deer in arid environments. 
Habitat use in arid environments has been studied from various perspectives: presence-absence by habitat, use-availability analysis (Fox and Krausman 1994), comparison of habitats on a usage gradient, according to structural differences (Bowyer et al. 1998), and in the context of management practices (Rollins et al. 1988). Beier and McCullough (1990) considered the activity of individuals and habitat use simultaneously and found diel shifts in habitat use by season. A study of habitat preference in conjunction with tracking individual animal's behavior would help us understand how individual requirements can influence habitat use, however little research has been done from this perspective.

Several studies (Ockenfels et al. 1991, Boroski and Mossman 1996, Rosenstock et al. 1999) have mentioned that habitat preference is influenced by water availability. Our goal was to characterize 7 different habitats and record the preferences and activities of white-tailed deer $(O, v$. texanus, Mearns 1898) by season, sex, and year, in each habitat type on a ranch with high water availability. With 3.4 water sources $\mathrm{km}^{-2}$, the San Francisco Ranch in Nuevo Leon, Mexico, provided the opportunity to explore the importance of other factors that may affect habitat use by deer when water is abundant. We tested the following hypothesis: When water availability is high, habitat preferences are determined by the availability of food and cover provided by the vegetation. We predicted that deer prefer habitats with sparse thermal cover but plentiful food and that deer avoid zones with good thermal cover, but low available food, even during the driest periods.

\section{Methods}

\section{Study Area}

This research was carried out on the San Francisco Ranch $\left(27^{\circ} 20^{\prime} \mathrm{N}, 100^{\circ} 36^{\prime} \mathrm{W}\right)$, property of Ducks Unlimited of Mexico,
A.C. (DUMAC), located between the municipalities of Lampazos, Nuevo Leon and Progreso, Coahuila, in northeastern Mexico (Fig.1). The ranch covers 1,500 ha, 1,000 of which are enclosed by a 2.4 meter high fence, the only purpose of which is to keep the deer in. An intensive water management program (3 ephemeral streams with dams and 32 water troughs) operate in the enclosed area: the average distance between these water sources is

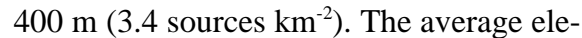
vation of the area is $430 \mathrm{~m}$, with a fairly flat topography and slopes that vary between 3 and $8^{\circ}$. The climate is semiarid, with a mean annual temperature of $21^{\circ} \mathrm{C}$. On occasion, the maximum temperature exceeds $40^{\circ} \mathrm{C}$. Annual rainfall averages less than $400 \mathrm{~mm}$ (Fig. 2), with notable variations in both monthly and total annual rainfall. The rainy season lasts from May to September. There are few cattle on the ranch, approximately 20-30 head which are rotated and kept within the fenced 1,000 ha for short periods of time.
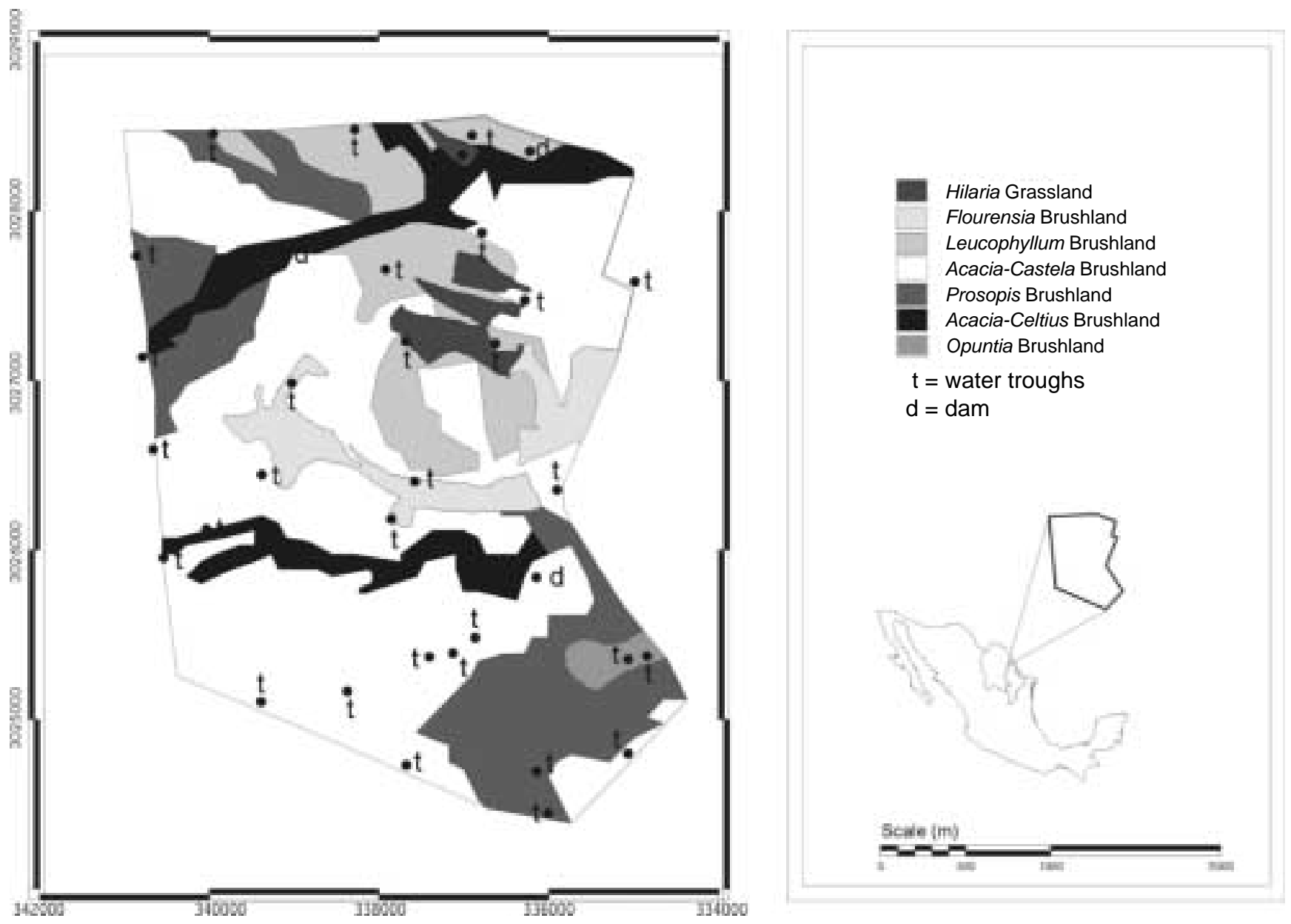

Fig. 1. Location of the San Francisco Ranch, Mexico and map of vegetation associations. Classification modified from Briones (1984) 


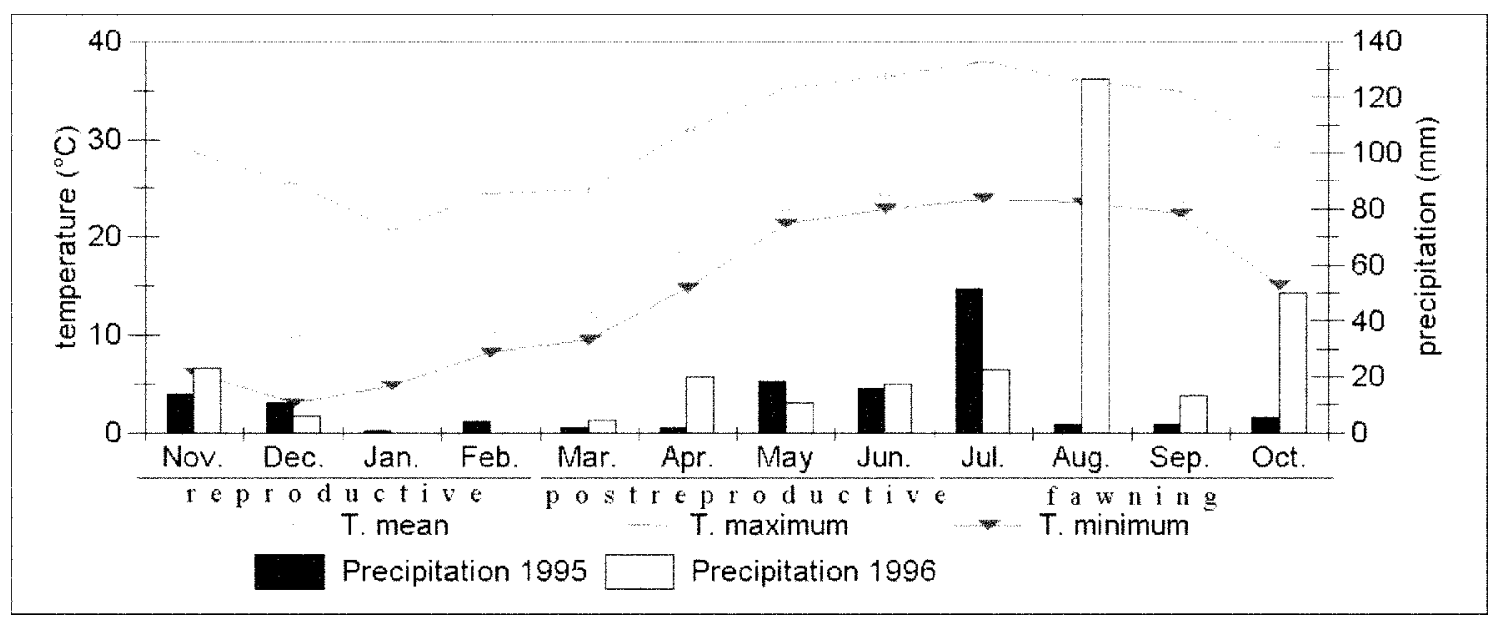

Fig. 2. Temperature and rainfall data during 1995 and 1996 for the Venustiano Carranza dam, localized $10 \mathrm{~km}$ from the study area.

The deer population varies from 80 to 100 animals. Vegetation in this zone is xerophyllous brushland that is found in a transitional zone between 2 physiographical provinces: the Coastal Plain of the Northern Gulf and the North American Great Plains (Briones 1984). The area has a variety of species characteristic of both provinces: cenizo (Leucophyllum frutescens Berl. Johnst), chaparro prieto (Acacia rigidula Benth), hojasen (Flourensia cernua DC), and gobernadora (Larrea tridentata (DC)Cov.). Briones (1984) determined 7 types of habitats for the municipality of Lampazos, Nuevo León, 6 of which were found in the study area: Hilaria grassland, Leucophyllum brushland, Flourensia brushland, AcaciaCastela brushland, Prosopis brushland, and Acacia-Celtis brushland. Additionally, after sampling the vegetation in this zone, we included another brushland habitat, Opuntia.

\section{Vegetation Characteristics}

Digital maps of vegetation and water sources on the San Francisco Ranch were made using the ILWIS geographic information system (ITC 1993). A map of habitats based on Briones's (1984) classification, was produced by aerial photograph interpretation $(1: 50,000)$, and field verification, which allowed us to correct the limits for some of the habitats.

Vegetal characteristics of each habitat type were estimated by first randomly establishing 400-meter-long transects, each with 10 sampling points in the 7 habitats. In all, 17 transects were established, and the number of transects per habitat varied from 1 to 9 , depending on the relative area occupied by each habitat.
The first point of a transect was placed randomly and the rest were spaced 40 meters apart. Brush species were sampled with the point-centered quarter method (Brower et al. 1990) at each point. For each point the following vegetation variables were measured: richness of plant species, height, distance from the nearest neighbor, density, horizontal and vertical vegetation cover. We also estimated volume of edible species, non-edible species, and total volume.

Thermal cover or protection offers shade which is important for ungulates exposed to heat stress (Mysterud and Ostbye 1999). We used the horizontal cover of brush (the horizontal area of plant foliage) as an estimate of thermal cover, and this was calculated by measuring 2 right angle diameters for each shrub and assuming the shape of an ellipse for the canopy.

Vertical cover was used as an indicator of hiding cover, which may benefit deer by reducing the possibility of detection and hence predation (Mysterud and Ostbye 1999). Hiding cover was estimated using a cover pole following the method described by Griffith and Youtie (1988). We used a $0.10 \mathrm{~m} \times 2 \mathrm{~m}$ hardwood cover pole, with 4 horizontal divisions of $50 \mathrm{~cm}$ as strata labeled: $0-50 \mathrm{~cm}, 51-100 \mathrm{~cm}$, $101-150 \mathrm{~cm}$ and $151-200 \mathrm{~cm}$. Each stratum was painted with 5 alternating $0.1 \mathrm{~m}$ black and white bands. The cover pole was placed $15 \mathrm{~m}$ away from and perpendicular to each sampling point on the transect. From this position, 2 readings ( 1 on each side) were taken at each sampling point. Hiding cover estimates were calculated as the percentage of the pole concealed by vegetation at each stratum. Each painted band was equivalent to $20 \%$ cover.
For these readings, a painted band was considered "covered" when at least $25 \%$ was obscured by vegetation. Average cover was obtained for each stratum as well as the total for each transect.

We calculated the total volume of each bush per transect assuming an approximated shape of an inverted cone. This value was used as an indicator of the biomass potentially available to deer. Although these values could be overestimated, especially for individuals of the Opuntia genus, we considered the bias would be constant among habitats. In addition, the volume of the most edibles species was determined as well as the volume of the less edible species. According to current literature (Martínez et al. 1997, Villarreal 1999), the 7 species important in the diet of deer are; Acacia rigidula, A. berlandieri, A. greggi, Porlieria angustifolia, Prosopis sp., Opuntia sp., and $O$. leptocaulis. We further determined the percentage of total volume of edible and less edible species for each habitat. We predicted the relative potential importance of each habitat for 3 basic requirements of deer (forage, thermal and hiding cover), in accordance with the values of habitat variables mentioned above.

We conducted a Principal Components Analysis (PCA) to order the vegetation transects relative to the selected habitat variables. This allowed us to determine which variables are associated with and characterize each of these habitats. The matrix was created using standardized and centered data which was then analyzed using the program STATISTICA (Statsoft 1998). Other variables also employed in this analysis were: variance in height, mean distance to the nearest neighbor, and variance in cover. 


\section{Radiotelemetry}

From September 1994 through November 1995, we used a dropnet to capture 14 deer ( 7 males and 7 females). Each deer was equipped with a uniquely colored radiocollar with a specific frequency and activity sensor. Animals were relocated with a pair of TR-4 receptors (Telonics, Inc., Meza, Ariz.) and 2 portable "H"-type antennas at 2 fixed georeference stations. Paired compass readings per animal were taken simultaneously by hour over 24-hour cycles, with 2 or 3 cycles each month during 1995 and 1996. Although these data are autocorrelated, longer time intervals could produce larger variability within the data sets, reducing the comparison power and sacrificing behavioral information of biological significance (Reynolds and Laundré 1990). The Universal Transversal Mercator (UTM) coordinates were obtained using the Tripoly Program (Laundré 1990), assuming a magnetic deviation of $9.15^{\circ}$. For the purposes of sampling, we considered 3 deer biological periods, each with unique energy requirements: reproduction or breeding (November-February, the dry period), postreproduction or gestation (March-June, the dry period), and fawning (July-October, the rainy season).

\section{Deer Habitat Preference}

To analyze habitat preferences, we overlaid a vegetation map with the deer location coordinates, thus illustrating deer use for each habitat. A habitat was considered "preferred" when it was used to a greater extent than expected, according to its availability (Byers et al. 1984). Preference for each habitat was determined by 2 methods using the Generalized Linear Models program (GLIM; NAG 1993). We used GLIM because it is useful in handling difficult data sets (non-normal) and problems such as non-orthogonal designs (Crawley 1993). First, we regressed the seasonal number of locations of each individual within each habitat against the area of each habitat. This enabled us to test if the number of locations by habitat type depended on its availability, and on the variables sex, season, or year. A positive regression indicated that the number of locations was determined by the availability of each habitat, while any other result indicated preferences for certain habitats. Second, a log-linear model assuming a Poisson error distribution was used to determine which habitats were either preferred or avoided, and whether preferences were affected by the variables: habitat ( 6 levels), sex (2 levels), season (3 levels), and year (2 levels). We use the log-linear model because it allows us to detect changes in preferences related to factors such as individual (sex, age) and time as year and season (Manly et al. 1993). When we fitted the models of preferences analysis, there was overdispersion of the scale factor, which could have produced an error in the test of hypothesis. Therefore, we calculated the scale factor from the residual deviance before running the analysis with overdispersion, and used the $F$ statistic distribution as reference (Crawley 1993).

\section{Deer Activity}

We recorded the behavior of deer at the same time the animals were relocated. The type of behavior was identified by counting the number of beeps emitted by the activity sensor per minute during $5 \mathrm{~min}$ intervals. In an earlier study with captive deer using collars with sensors, Mandujano et al. (1996) demonstrated $90 \%$ accuracy in distinguishing 3 activity patterns of the deer behavior based on the beep frequency: bedding (50-55 beeps per minute), searching (56-69 beeps per minute) and feeding (70-87 beeps per minute). We counted the number of locations per habitat classified by activity (bedding, searching, and feeding) by sex, season and year. The number of locations expected for each activity in each habitat was calculated by multiplying the total number of locations by activity by the relative availability of each habitat. We determined habitat preferences by activity using a chi-square analysis in GLIM. When there were problems of overdispersion in the models, these were dealt with by using a correction factor similar to that used in the preference analyses.

\section{Results}

\section{Vegetation Characteristics}

Based on the attributes of the 7 habitats (Table 1), we ranked the different habitats relative to their importance value for deer requirements as follows.

Table 1. Variables in each habitat type on the San Francisco Ranch, Mexico and their relative potential importance for 3 basic requirements of deer. $(\mathrm{A}=$ Acacia-Castela, $\mathrm{F}=$ Flourensia, $\mathrm{H}=$ Hilaria, $\mathrm{L}=$ Leucophyllum, $\mathrm{O}=$ Opuntia, $\mathrm{P}=$ Prosopis and $\mathrm{C}=$ Acacia-Celtis; for importance value $1=$ low, $2=$ medium, and $3=$ high $)$.

\begin{tabular}{|c|c|c|c|c|c|c|c|}
\hline \multirow[b]{2}{*}{ Variable } & \multicolumn{6}{|c|}{ Habitat } & \multirow[b]{2}{*}{$\mathrm{C}$} \\
\hline & A & $\mathrm{F}$ & $\mathrm{H}$ & $\mathrm{L}$ & $\mathrm{O}$ & $\mathrm{P}$ & \\
\hline Transect number & 9 & 2 & 1 & 1 & 1 & 2 & 1 \\
\hline Richness (No. species) & 10 & 11 & 9 & 10 & 5 & 7 & 6 \\
\hline Brush density (ind/ha) & 199 & 265 & 5 & 118 & 10 & 49 & 81 \\
\hline Thermal cover $\left(\mathrm{m}^{2}\right)$ & 62.7 & 49.7 & 53.6 & 45.4 & 51.9 & 88.6 & 154.6 \\
\hline Hiding cover $0-50(\%)$ & 60.2 & 56.0 & 15.0 & 68.0 & 8.3 & 76.0 & 100.0 \\
\hline Hiding cover $51-100(\%)$ & 39.1 & 13.5 & 2.0 & 25.0 & 0.0 & 54.5 & 95.0 \\
\hline Total hiding cover $(\%)$ & 39.5 & 25.0 & 6.3 & 34.3 & 2.8 & 52.5 & 97.0 \\
\hline Mean distance (m) & 3.6 & 2.8 & 21.4 & 2.9 & 10.2 & 4.5 & 3.5 \\
\hline Mean height (m) & 1.2 & 1.0 & 1.5 & 1.2 & 0.8 & 1.4 & 2.4 \\
\hline Variance thermal cover $\left(\mathrm{m}^{2}\right)$ & 2.8 & 2.4 & 1.4 & 1.0 & 2.8 & 4.6 & 14.8 \\
\hline Variance height $(\mathrm{m})$ & 0.2 & 0.1 & 6.8 & 0.1 & 0.1 & 0.2 & 0.9 \\
\hline Total volume $\left(\mathrm{m}^{3}\right)$ & 37.5 & 29.6 & 37.7 & 26.7 & 16.8 & 58.3 & 187.1 \\
\hline Edible Species volume $\left(\mathrm{m}^{3}\right)$ & 13.7 & 14.5 & 28.5 & 7.6 & 16.3 & 39.6 & 127.4 \\
\hline Not edible Species volume $\left(\mathrm{m}^{3}\right)$ & 23.7 & 15.1 & 9.2 & 19.2 & 0.5 & 18.6 & 59.7 \\
\hline Edible volume percentage $(\%)$ & 41.2 & 35.8 & 75.5 & 28.4 & 96.9 & 64.7 & 68.1 \\
\hline Not edible volume percentage $(\%)$ & 58.8 & 64.2 & 24.5 & 71.6 & 3.1 & 35.3 & 31.9 \\
\hline Foraging value & 1 & 1 & 2 & 1 & 1 & 3 & 3 \\
\hline Hiding value & 3 & 2 & 1 & 2 & 1 & 3 & 3 \\
\hline Thermal value & 3 & 2 & 1 & 1 & 1 & 3 & 3 \\
\hline
\end{tabular}


Table 2. Results of Principal Components Analysis of habitat variables for component 1 and component 2 on the San Francisco Ranch, Mexico $(*=P<0.05)$.

\begin{tabular}{|c|c|c|c|}
\hline \multirow[b]{2}{*}{$\begin{array}{l}\text { Variable } \\
\text { number }\end{array}$} & \multirow[b]{2}{*}{ Variable } & \multicolumn{2}{|c|}{ Component } \\
\hline & & 1 & 2 \\
\hline 1 & variance thermal cover $\left(\mathrm{m}^{2}\right)$ & -0.589 & -0.434 \\
\hline 2 & variance height $(\mathrm{m})$ & $-0.925 *$ & -0.128 \\
\hline 3 & Brush density (ind $\left./ \mathrm{km}^{2}\right)$ & 0.314 & 0.664 \\
\hline 4 & Richness (No. Species) & 0.323 & 0.209 \\
\hline 5 & Thermal cover $\left(\mathrm{m}^{2}\right)$ & $-0.932 *$ & -0.162 \\
\hline 6 & Hiding cover $0-50(\%)$ & -0.646 & 0.683 \\
\hline 7 & Hiding cover $51-100(\%)$ & $-0.759 *$ & 0.517 \\
\hline 8 & Total hiding cover $(\%)$ & $-0.799 *$ & 0.519 \\
\hline 9 & mean distance $(\mathrm{m})$ & 0.098 & $-0.891^{*}$ \\
\hline 10 & mean height $(\mathrm{m})$ & $-0.905^{*}$ & -0.281 \\
\hline 11 & total volume $\left(\mathrm{m}^{3}\right)$ & $-0.970 *$ & -0.136 \\
\hline 12 & Edible Species volume $\left(\mathrm{m}^{3}\right)$ & $-0.887 *$ & -0.293 \\
\hline 13 & Not edible Species volume $\left(\mathrm{m}^{3}\right)$ & $-0.824 *$ & 0.207 \\
\hline 14 & Edible volume percentage $(\%)$ & -0.090 & -0.676 \\
\hline
\end{tabular}

Forage: Although Acacia-Celtis brushland was comprised of only 6 species, including small trees of Acacia farnesiana, this habitat had the highest total and edible species volume, and was considered to provide good conditions for foraging activity. Mean height was $2.6 \mathrm{~m}$ and this habitat was common around the ephemeral streams and their dams. Although vegetation density was low, we considered Prosopis brushland a good foraging habitat because it had the second highest volume of edible species, and a richness of 7 species. In the Hilaria habitat we included some man-made meadows mixed with fragments of other habitats found at the study area. Nine plant species were detected. Although this habitat had the lowest individual density, its bushes were relatively tall (mean height $1.5 \mathrm{~m}$ ) and $75 \%$ of total volume was edible, thus this habitat could be an important source of forage for deer. The Acacia-Castela brushland had 10 species and a mean brush density of 199 individuals/ha, however the volume of edible species was one of the lowest and we considered it less important for deer foraging. We considered Flourensia, Leucophyllum and Opuntia to be unattractive habitats for foraging because they had a low volume of edible species, even though Flourensia and Leucophyllum had high species richness. We did however find a few signs of browsing on Opuntia by deer on the ranch.

Hiding cover: With the highest values of overall hiding cover. Acacia-Celtis, Prosopis and Acacia-Castela provided good conditions for bedding and searching. The Leucophyllum brushland had high hiding cover in the $0-50$ stratum, and although it diminished in the other 2 levels, we still considered it as good protec- tion habitat by deer. In the case of Flourensia brushland, the hiding cover in the 0-50 stratum, important for fawns, was $56 \%$, but total cover was among the lowest because mean height was only 1.0 m. Finally, the Hilaria and Opuntia habitats had the lowest values for hiding cover, and were considered the least important for deer protection against predators.

Thermal cover: AcaciaCeltis, Prosopis and Acacia-Castela habitats had the highest thermal cover and offered good conditions as bed sites of deer. Flourensia brushland had the highest density of individual plants, but lower thermal cover compared to the above habitats. Thermal protection diminished in Hilaria, Opuntia and Leucophyllum (the lowest) habitats and we considered these habitats as unattractive as bedding sites.

The transect ordination shown in Figure $3 \mathrm{a}$ is based on the first 2 principal components, which accounted for $74 \%$ of the variance. The first component $(51 \%$ variance explained) was correlated significantly with total volume, volume of edible and non-edible species, thermal and hiding cover, and variance in cover (Table 2). This component effectively separated habitats relative to cover and food: Acacia-Celtis and Prosopis, as well as 2 Acacia-Castela transects that registered the highest values of the abovementioned variables for this habitat vs the habitats of Leucophyllum, Flourensia, Hilaria, and Opuntia with lower cover and volume (Fig $3 \mathrm{a}$ and $3 \mathrm{~b}$ ). The second component ( $23 \%$ of the variance explained) separated the dense habitats from the open ones, as indicated by the mean distance between individual plants. The Opuntia and Hilaria habitats were the most open habitats with average distances of 21.3 and $10.2 \mathrm{~m}$, respectively.

\section{Habitat Preferences By Deer}

We recorded 4,909 deer locations and these varied per sample populations from none in the Opuntia habitat to 926 in Acacia-Castela brushland (Table 3). As deer did not use the Opuntia habitat, we did not include it in the GLIM analysis, and thus avoided bias in the preferences

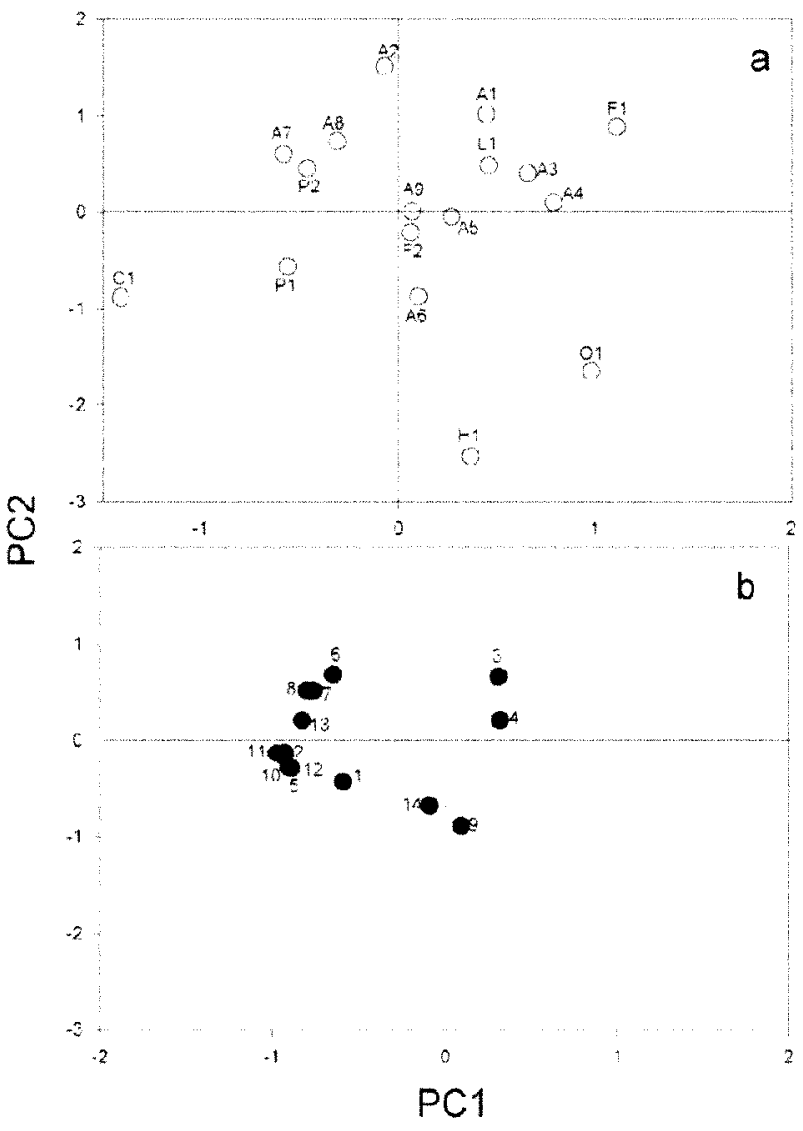

Fig. 3. Principal Components Analysis for vegetation transects on the San Francisco Ranch, Mexico(a) and relationship among environmental variables of the Table $2(\mathrm{~b}) .(\mathrm{A}=$ Acacia-Castela, $\mathbf{F}=$ Flourensia, $\mathrm{L}=$ Leucophyllum, $\mathrm{H}=$ Hilaria, $\mathrm{O}=$ Opuntia, $\mathrm{P}=$ Prosopis and $\mathrm{C}=$ Acacia-Celtis $)$. 
Table 3. Estimated area, and location numbers of white-tailed deer for each habitat association by sex on the San Franscisco Ranch during 1995 and 1996. Percentages are shown in brackets.

\begin{tabular}{|c|c|c|c|c|c|}
\hline \multirow[b]{2}{*}{ Plant association } & \multirow[b]{2}{*}{ area (ha) } & \multicolumn{2}{|c|}{1995} & \multicolumn{2}{|c|}{1996} \\
\hline & & female & male & female & male \\
\hline Opuntia & $11(1.1)$ & 0 & 0 & 0 & 0 \\
\hline Hilaria & $30(3)$ & $15(1)$ & $42(3)$ & $82(6)$ & $89(10)$ \\
\hline Leucophyllum & $117(11.6)$ & $13(1)$ & $115(9)$ & $178(13)$ & $251(29)$ \\
\hline Flourensia & $60(5.9)$ & $212(15)$ & $243(18)$ & $127(10)$ & $19(8)$ \\
\hline Acacia-Castela & $546(54)$ & $926(65)$ & $658(51)$ & $673(51)$ & $316(49)$ \\
\hline Prosopis & $149(14.7)$ & $76(5)$ & $89(7)$ & $61(5)$ & $23(8)$ \\
\hline Acacia-Celtis & $98(9.7)$ & $191(13)$ & $146(11)$ & $195(15)$ & $169(11)$ \\
\hline
\end{tabular}

analysis by small frequencies. We found a positive relationship $(\mathrm{r}=0.55, \mathrm{P}<0.05)$ between habitat availability and the number of locations by habitat (Fig. 4a), but the data formed 2 separate clusters that correspond to the Acacia-Castela brushland and the other 5 habitat types. Suspecting that the high availability of Acacia-Castela brushland (54\%) was responsible for this result, we performed a second regression analysis (Fig. 4b) excluding this habitat type. The result was no relationship between habitat availability and frequency of locations $(\mathrm{r}=0.06, \mathrm{P}$ $>0.05$ ). The lack of correlation between these 2 variables indicates habitat preference on the part of deer, and the preference was masked by the high availability of Acacia-Castela brushland.

Preferences were influenced by habitat type, sex, and year $\left(\mathrm{F}_{5,156}=13.5, P<<\right.$ $0.00001)$. During 1995, females avoided Hilaria and Leucophyllum, while they preferred areas of Flourensia, Acacia-
Castela, and Acacia-Celtis. The high cover Prosopis habitats were used according to availability (Fig. 5a). Males however, selected most of the habitat types according to availability, showing preference only for Flourensia habitats. During 1996, females preferred Hilaria, avoided Prosopis and Acacia-Castela habitats, while their use of Leucophyllum, Flourensia, and Acacia-Celtis was based on relative availability (Fig. 5b). Males preferred Hilaria and Acacia-Celtis habi-

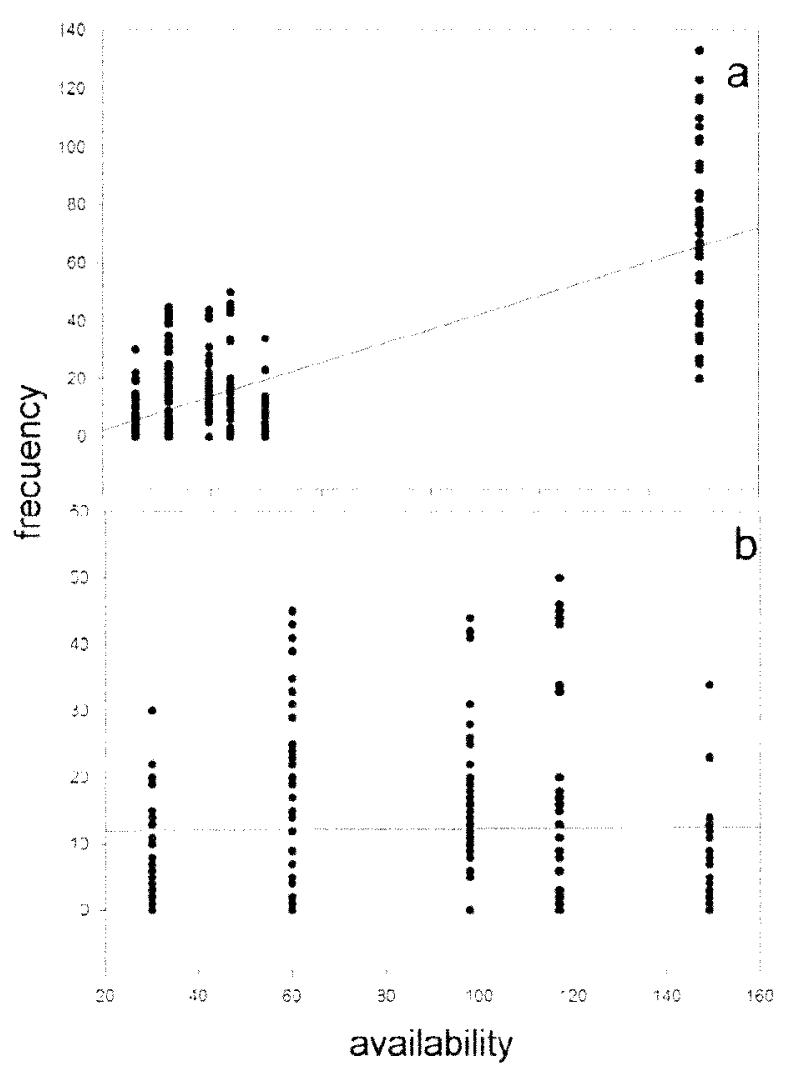

Fig. 4. Regression analysis of data on habitat use of deer and availability of each vegetation association on the San Francisco Ranch, Mexico with (a) and without (b) the Acacia-Castela habitat.

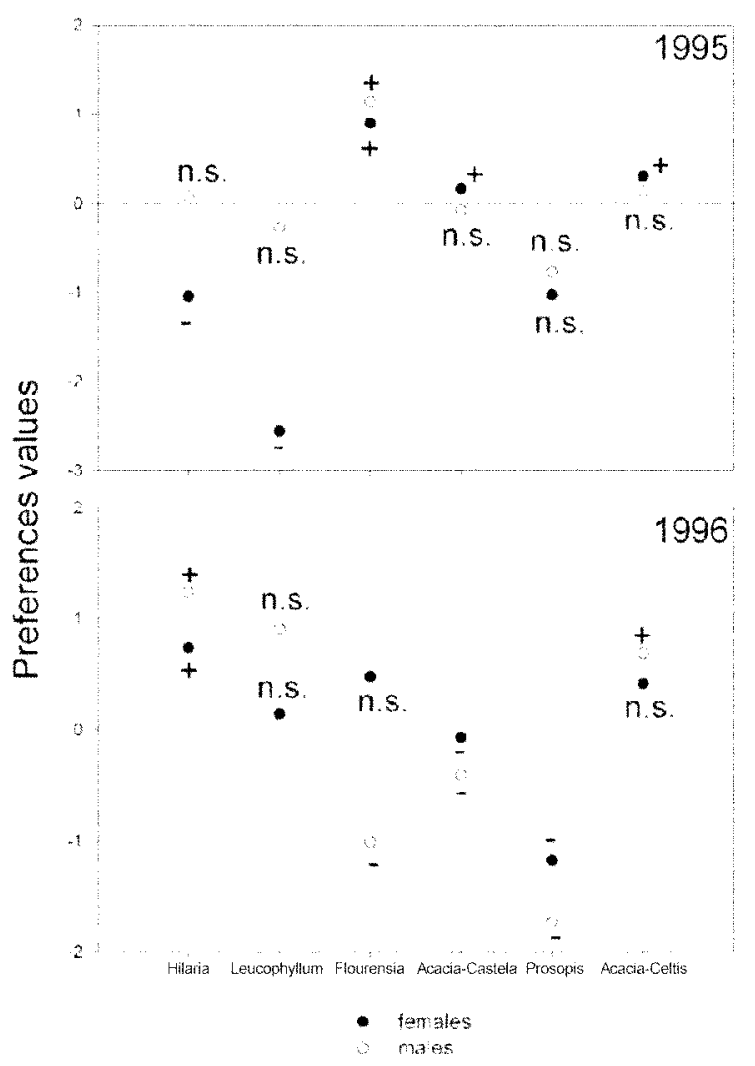

Fig. 5. Habitat preferences of white tailed deer by sex on the San Francisco Ranch, Mexico during 1995 (a) and 1996 (b). The sign "+" indicates preference, the sign "-" indicates avoidance, "n.s" indicates use according to availability. 

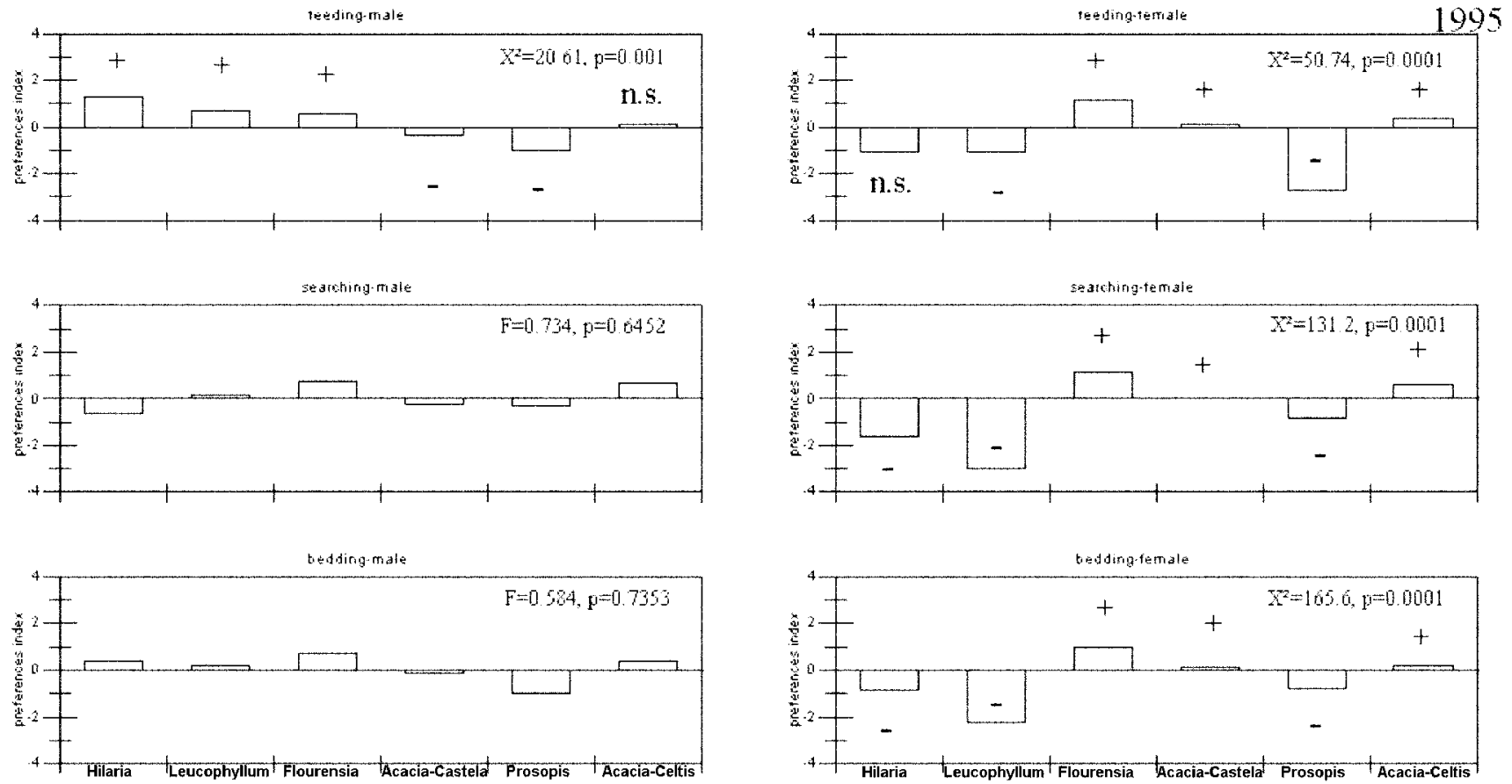

Fig. 6. Deer activity in each habitat by sex in 1995 on the San Francisco Ranch, Mexico. The sign "+" indicates preference, the sign "_" indicates avoidance, "n.s" indicates use according to availability.

tats, while Flourensia, Acacia-Castela, and Prosopis were avoided (Fig. 5b).

\section{Deer Activity}

There was also variation in each habitat for the 3 activities studied between sexes and years (Fig. 6). Both sexes used the Prosopis brushland less than expected, for the 3 activities during both years. For feeding activity during 1995, males preferred the Hilaria, Leucophyllum and Flourensia habitats and avoided AcaciaCastela and Prosopis. Females preferred the Flourensia, Acacia-Castela and Acacia-Celtis habitats for all activities and avoided Hilaria, Leucophyllum and Prosopis. In 1996, males preferred Hilaria, Leucophyllum and Acacia-Celtis for all activities (Fig. 7). They avoided Flourensia, for feeding and bedding and Acacia-Castela and Prosopis, for all 3 activities. In 1996, females used all the habitats according to availability for all 3 activities. Hilaria was used more by females than in 1995, and there was less use of Flourensia and Acacia-Celtis than in 1995.

\section{Discussion}

The habitats found within the San Francisco Ranch had markedly different characteristics, some had high cover values and others a high value of edible species. Therefore each habitat can, depending on its specific environmental conditions, meet different requirements for deer. Accordingly, we found that deer did exhibit habitat preferences and that these preferences for different habitats depended on sex and year. Habitats with dense cover, with the exception of Prosopis, were important for all female activities during 1995, whereas males only preferred the dense cover zones of Acacia-Celtis in 1996. Cover protection against predators and harsh temperatures is an important element in deer habitat (Kroll 1992, Olson 1992). In Texas, the areas most heavily used by deer have dense cover that often exceeds $80 \%$ (Pollock et al. 1994); on the San Francisco Ranch, Acacia-Castela, Prosopis and Acacia-Celtis brushland also had hiding cover with similar values. Wiggers and Beasom (1986) state that in general, cover of $53 \%$ or more is considered favorable to white-tailed deer, because it offers protection against predators such as coyote (Canis latrans), bobcat (Lynx rufus), and cougar (Puma concolor). It has been determined that on the San Francisco Ranch, deer make up $8 \%$ of the coyote's diet (López-Rivera and Gallina 1998). Predation data for cougars is limited and unavailable for the bobcat. Although these predators are found in our study area, and the fences did not limit their movements in and out of the ranch, predation was generally low. The main difference between years is a result of more deer being attacked and killed in 1995 when, perhaps attracted by the abundant drinking water, 2 dogs entered the study area. DeStefano et al. (2000) address the issue of water developments attracting predators and impacting prey populations. According to workers on this ranch, there were more deaths in 1995 than in 1996. These dogs were killed at the end of the fawning period in 1995 and were not a problem in 1996, although cougars and coyotes continued to be present. This was the only measure of predator control taken during the study period. The drought conditions that influenced the physical condition of the deer during 1995, as well as predation by the feral dogs, could have caused the deer to adopt a defensive strategy. This may explain why females preferred locations with good cover, such as the Acacia-Castela and Acacia-Celtis plant associations during 1995.

In general, males showed limited habitat preference in 1995, and during 1996 they preferred open areas, only using certain habitats of dense cover. Therefore, they depended on dense cover zones for fewer activities than females did. This preference for open habitats contrasts with results from other studies (Wood et al. 
feeding-miale

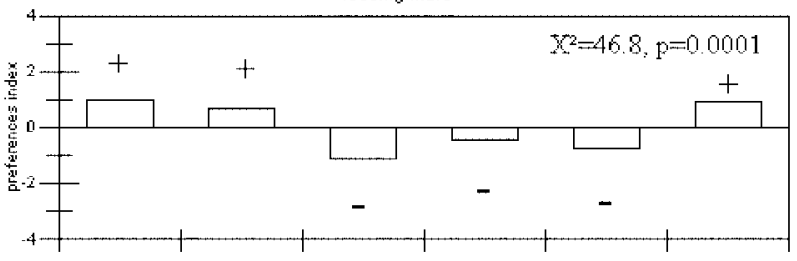

sanathing-male

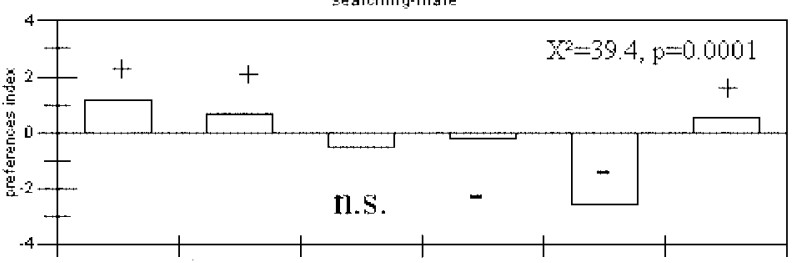

beding-mal

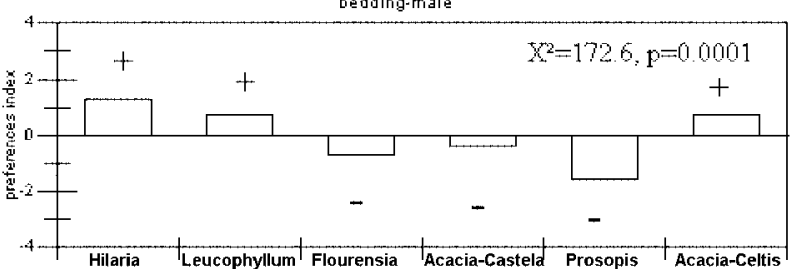

feeding-teriale
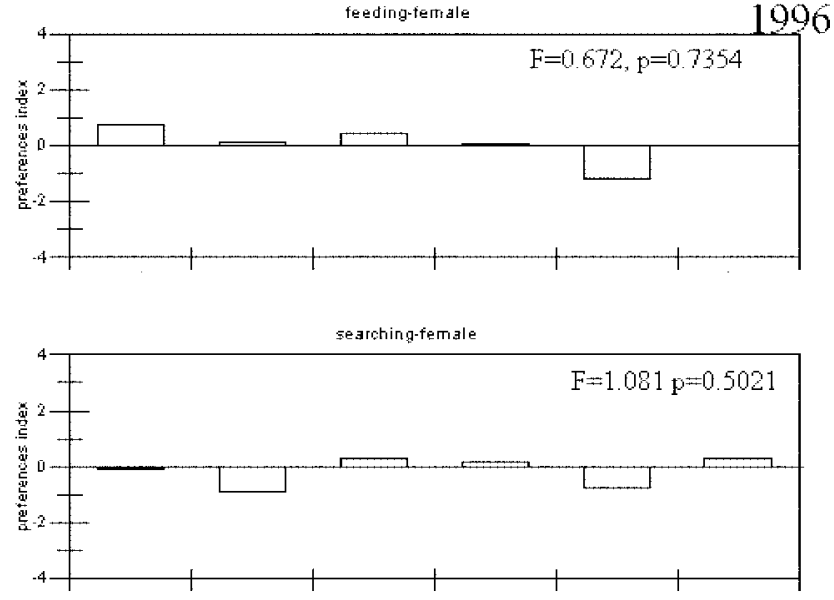

bédiding-temale

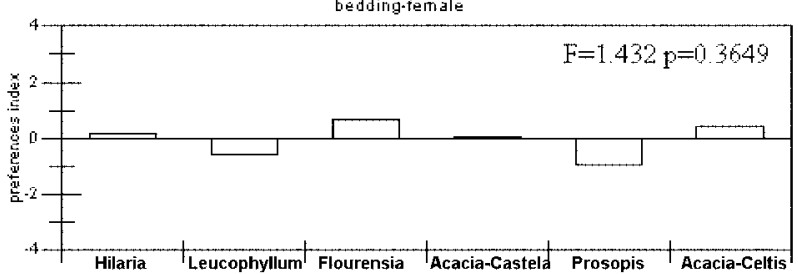

Fig. 7. Deer activity in each habitat by sex in 1996 on the San Francisco Ranch, Mexico. The sign "+" indicates preference, the sign "-" indicates avoidance, "n.s" indicates use according to availability.

1989, Ockenfels et al. 1991) which show that deer of both sexes tend to avoid open areas. In fact, there are areas where cover is thought to be the determining factor in selection, more for favorable thermal cover conditions than hiding cover (Bowyer et al. 1998). This selection is a result of frequent high temperatures (over $30^{\circ} \mathrm{C}$ ) that cause water loss from evapotranspiration (Ockenfels and Bissonette 1984). Under these harsh circumstances, deer move to areas with good cover in order to avoid thermal stress (Pollock et al. 1994). The different male behavior observed on the San Francisco Ranch could be due, as we expected, to the high availability of water, but also to the good vegetation cover, which allowed them to venture beyond dense cover zones to open areas such as Hilaria and Leucophyllum to forage and search. This behavior has been reported in other studies (Mysterud and Ostbye 1999)

Females preferred zones with high cover during 1995, but not in 1996. Both the habitats they avoided and those that they preferred during 1995, were used according to habitat availability in 1996. This variation is probably a result of the marked differences in precipitation between years (1995: $136 \mathrm{~mm}$; 1996: 276 $\mathrm{mm})$. Because drinking water was abundant in both years owing to the water man- agement program, the yearly variation in habitat use was likely a result of some other changes in habitat characteristics that we did not measure. Since we only have data for 2 years, it is difficult to analyze this possibility with any greater precision. Nevertheless, variability in precipitation in arid zones has been observed to modify habitat conditions (Davis 1990), mainly the availability of food and cover (Kie and Thomas 1988). Seasonal variation in site use as a result of these sources of variation, as well as individual requirements, has been reported in other studies (Orians and Wittenberger 1991, Pollock et al. 1994). Thus the higher precipitation in 1996 likely improved forage conditions in all the habitats of the San Francisco Ranch, and gave deer a greater selection from which to choose. This resulted in greater use of open areas by females in 1996 compared to 1995 , and could explain why females used Acacia-Celtis less for feeding during 1996.

Females avoided Hilaria habitat during 1995 , but preferred it in 1996 . When we look at the habitat preferences by activity, the use of Hilaria for feeding activity increased during this wet year, likely because it had a greater diversity of nutritious, edible species according to Davis (1990). This association is comprised of a mixture of grassland and dense brushland; such a combination is attractive for deer (Wood et al. 1989, Kroll 1992) as it encourages the production of herbaceous species and greater diversity of brush species, both important elements in deer diet during the rainy season (Rollins et al. 1988). Flourensia was important for the feeding activity of both sexes in 1995, and for males in 1996. Leucophyllum was preferred by males during 1996. Both of these plant habitats had less food available than the other types and, in particular, F. cernua is not very palatable browse (Estell et al. 1994). The use of these 2 habitats could be explained by their relatively high species richness, which provided a variety of plants and plant parts that allow deer to meet their dietary needs (Davis 1990). The few signs of browsing on Opuntia by deer we observed on the ranch, may indicate that deer consume Opuntia to complement nutrient intake, but this is a subject for further study.

\section{Conclusions}

The behavior of white-tailed deer on the San Francisco Ranch differs markedly from that observed in arid zones where water is a limiting factor. Thermal cover requirements for protection against extreme temperatures were relatively low 
during 1996 as precipitation that year was higher than in 1995. In general, this improved habitat conditions and, specifically, increased thermal and hiding cover, food availability and reduced thermal stress. This may explain why open zones were preferred while the Prosopis zone, with high hiding and thermal cover, was avoided. The need for hiding cover decreased in 1996 since predation by dogs was eliminated. In contrast, 1995 was characterized by extreme drought and, although drinking water was abundant, food availability was lower. Deer sought and used dense cover more frequently, and were subjected to higher predation, mainly by dogs. The observed variation in the preferences of both sexes from year to year reminds us that habitat use is a complex process. For arid zones during years when drinking water is available all year round, and when predation is low and weather conditions are good with normal to abundant precipitation, the quality (i.e. diversity of species) and quantity of available forage is a key factor in determining habitat use by deer. However, when drought or predation increases, thermal and hiding cover become relatively more important than forage availability. From this we can conclude that, in addition to the availability of drinking water, effective water management programs in arid zones must also consider taking measures to maintain brushland with good thermal and hiding cover for deer to mitigate the effects of harsh weather and predation.

\section{Literature Cited}

Beier, P. and D.R. McCullough. 1990. Factors influencing white-tailed deer activity patterns and habitat use. Wildl. Monogr. No 109.

Bleich, V.C., R.T. Bowyer, and J.D. Wehausen. 1997. Sexual segregation in mountain sheep: resources or predation? Wildl. Monogr. No 134.

Boroski, B.B. and A.R. Mossman. 1996. Distribution of mule deer in relation to water sources in northern California. J. Wildl Manage. 60:770-776.

Bowyer, R.T., J.G. Kie, and V.V. Ballenberghe. 1998. Habitat selection by neonatal black tailed deer: climate, forage, or risk of predation? J. Mammal. 79: 415-425.

Briones, V. O. 1984. Sinecología and florística de Lampazos de Naranjo, Nuevo León (México), con enfasis en la Gran Llanura (In Spanish). Bachelor thesis. Universidad Autónoma de Nuevo León. Linares, Nuevo León, México.

Brower, J. E., J. H., Zar, and C. N. von Ende 1990. Field and Laboratory methods for general ecology. Wm.C. Brown Publishers. Dubuque, Iowa.
Byers, C.R., R.K. Steinhorst, and P.R. Krausman 1984. Clarification of a technique for analysis of utilization-availability data. J. Wildl. Manage. 48:1050-1053.

Crawley, M.J. 1993. GLIM for ecologists. Blackwell Scientific Publications, Oxford, UK.

Davis, E. 1990. Deer management in the south Texas plains. Texas Park and Wildlife Department. Federal aid reports series. No. 27. Austin, Tex.

DeStefano, S., S.L. Schmidt, and J.C. DeVos Jr. 2000. Observations of predator activity at wildlife water developments in southern Arizona. J. Range Manage. 53:255-258.

Estell, R.E., E.L. Fredrickson, D.M. Anderson, W.F. Mueller, and M.D. Remmenga. 1994. Relationship of tarbush leaf surface secondary chemistry to livestock herbivory. J. Range Manage. 47:424-428.

Fox, K.B. and P.R. Krausman 1994. Fawning habitat of desert mule deer. Southw. Natur. 39(3):269-275.

Griffith, B. and B.A. Youtie 1988. Two devices for estimating foliage density and deer hiding cover. Wildl. Soc. Bull. 16:206-210.

International Institute for Aerospace Survey and Earth Sciences (ITC). 1993. Ilwis 1.4. ITC. The Netherlands.

Kie, J.G. and J.W. Thomas 1988. Rangeland vegetation as wildlife habitat. pp 585-605. In: P.T. Tueller (Ed.) Vegetation science applications for rangelands analysis and management. Kluwer Academic Publishers.

Kroll, J.C. 1992. A practical guide to producing and harvesting white-tailed deer. Institute of White tailed deer Management and research center for applied studies in forestry. Stephen F. Austin State Univ. Austin, Tex.

Laundré, J.W. 1990. TRIPOLY. Intermountain Wildlife Research Institute. Idaho State Univ. Pocatelo, Ida.

Lopez-Rivera, N. D. and S, Gallina. 1998. Depredación de venado por coyote en una zona árida del noreste de México (In Spanish). pp. 106-110. In: Memorias del VI Simposio sobre venados de México. Fac. Med. Vet. Zoo. UNAM. I de E. ANGADI.

Mandujano, S., A. Pérez-Arteaga, R.E. Sanchez-Mantilla, and S.Gallina 1996. Diferenciación de pautas de actividad del venado con ayuda de radiotransmisores con sensor de movimiento (In Spanish). Acta Zoológica Mexicana (nueva serie) 67:613-620

Manly, B.F.J., L.L. McDonald, and D.L. Thomas. 1993. Resource selection by animals. Statistical design and analysis for field studies. Chapman \& Hall. London, U.K.

Martínez, M. A., V. Molina, S.F. González, J.S. Marroquín, and Ch.J. Navar 1997. Observations of white-tailed deer and cattle diets in Mexico. J. Range Manage. 50:253-257.

Mysterud, A. and E. Ostbye. 1999. Cover as a habitat element for temperate ungulates: effects on habitat selection and demography. Wildl. Soc. Bull. 27:385-394.
NAG (Numerical Algorithms Group). 1993. The statistical system for generalized linear interactive modelling. Oxford Univ. Press. Oxford, U.K.

Ockenfels, R.A. and J.A. Bissonette 1984. Temperature-related responses in north-central Oklahoma white-tailed deer. p 64-67. In: P.R. Krausman and N.S. Smith (Eds.) Deer in the southwest: a Workshop. Arizona Coop. Wildl. Reser. Unit and School of Renew. Nat. Resour. Univ. of Arizona. Tucson, Ariz.

Ockenfels, R.A., D.E. Brooks, and C.H. Lewis 1991. General ecology of Coues white-tailed deer in the Santa Rita Mountains. Arizona Game and Fish Dept., Tech. Rept. No 6, Phoenix, Ariz.

Olson, R. 1992. White tailed deer habitat requirements and management in Wyoming. Univ. of Wyoming. Laramie, Wyo.

Orians, G.H. and J.F. Wittenberger 1991. Spatial and temporal scales in habitat selection. Amer. Nat. 137:S29-S49.

Pollock, M. T., D.G. Whittaker, S. Demarais, and R.E. Zaiglin 1994. Vegetation characteristics influencing site selection by male white-tailed deer in Texas. J. Range Manage. 47:235-239.

Reynolds, T.D. and J.W. Laundré. 1990. Time intervals for estimating pronghorn and coyote home ranges and daily movements. J. Wildl. Manage. 54:316-322.

Rollins, D., F.C. Bryant, D.D. Waid, and L.C. Bradley 1988. Deer response to brush management in central Texas. Wildl. Soc. Bull. 16:277-284.

Rosenstock, S.S., W.B. Ballard, and J. C. deVos Jr. 1999. Benefits and impacts of wildlife water developments. J. Range Manage. 52:302-311.

StatSoft. 1998. STATISTICA 5.1'98 edition. Tulsa Okla

Villarreal, R. J. 1999. Venado cola blanca. Manejo y Aprovechamiento. Unión Ganadera Regional de Nuevo León, Monterrey, Nuevo León, México.

Wiggers, E.P. and S.L. Beasom. 1986. Characterization of sympatric or adjacent habitats of 2 deer species in west Texas. J. Wildl. Manage. 50:129-134.

Wood, A.K., R.J. Mackie, and K.L. Hamlin 1989. Ecology of sympatric populations of mule deer and white-tailed deer in a prairie environment. Montana Dept. Fish Wildl. and Parks, Bozeman, Mont. 